\title{
OPPORTUNITIES AND PROSPECTS FOR THE MASTER DEGREE OF EDUCATION OF SPECIALITY "ECOECONOMY"
}

\author{
Albena Miteva \\ University of National and World Economy, Department "Economy of Natural Resources", \\ Sofia, Bulgaria \\ albenakm@yahoo.com
}

\begin{abstract}
The masters degree of speciality "Eco-economy" has ben taught to the University of National and World Economy since 2012. It is taught for the first time in Bulgaria and meets the community needs of economists with built ecological attitude towards the use of natural resources and environmental preservation. On the basis of the two years period of education the opportunities for enhancement the educational curriculum of the speciality are highlighted and presented in the paper.
\end{abstract}

Key words: speciality "Eco-economy”; educational curriculum

\section{МОЖНОСТИ И ПЕРСПЕКТИВИ НА МАГИСТЕРСКИТЕ СТУДИИ НА ОБРАЗОВАНИЕ ЗА СПЕЦИЈАЛНОСТА „ЕКОЕКОНОМИЈА“}

\begin{abstract}
Магистерските студии за специјалноста „Еко-економија“ се изучуваат на Универзитетот за национална и светска економија од 2012 година. Таа се изучува за прв пат во Бугарија и ги задоволува барањата на општеството за економисти со изграден еколошки став кон користењето на природните ресурси и заштитата на околината. Врз основа на двегодишно образование се истакнати и презентирани можностите за подобрување на наставниот план и програма на специјалноста.
\end{abstract}

Клучни зборови: специјалност „Еко-економија“, наставен план и програма

\section{INTRODUCTION}

Eco-economy as a science started its structuring in the 60-70 years of $20^{\text {th }}$ century, and in the late $80 \mathrm{~s}$ was developed by numerous researchers and scientific institutions. During the academic year of 2010/2011 at the University of World and National Economy (UNWE) the educational process of master degree in eco-economy began. This was backed by the increasing environmental problems, deepening understanding of the relationship between man - society - environment and the need for environmental sound use of natural resources in different regions of the country in connection with EU requirements for expansion of environmental friendly measures in all production sectors. In connection with this the need for specialists and experts grows to work in the operational management of natural resources and environmental protection in various national and regional programs and strategies for development of rural regions and municipalities.

The purpose of this report is to review the curriculum for the Master's degree in "Eco-economy" and to suggest trends for optimizing the different scientific fields of the existing curriculum.

\section{RESULTS AND DISCUSSION OF THE REVIEW OF THE CURRICULUM OF THE MASTER'S DEGREE IN "ECO-ECONOMY"}

The training of students in master's degree of Eco-economy aims to prepare highly qualified specialists in economics, management and conservation of natural resources through the acquisition of fundamental and applied knowledge of legal regu- 
lation and assessment of impacts and the environmental consequences from economic activity. The contents of the master's degree in education is directed toward provision of in-depth specialized expert training to future graduates in economics, management and conservation of natural resources and environment. It is intended for economists and lasts 2 semesters $/ 1$ year/.

Main tasks for student education in the curriculum are as follows:

- To disclose the relationship man-societyenvironment;

- To develop skills to analyze and evaluate the interactions between the environment and the effects of the business management of natural resources;

- To acquire skills to develop project solutions suitable for implementation in practice and for their analysis;

- To develop practical knowledge and expertise to monitor and evaluate the economic environment, knowledge of the main economic instruments for environmental policy.

The main reasons for the preparation of specialists in Eco-economy are related to the need of specialists for new structural units for integration of our country and strengthening the administrative capacity of the Ministry of Environment and Water, Ministry of Regional Development and Public Works, Ministry of Agriculture and Food and other units involved in the management and administration of regional development and natural resources, regional development councils (in the six planning regions); regional plans for conservation, use and evaluation of natural resources, for the structures of the NGO sector which are equal partners in the implementation of regional development policies.

To meet these requirements, the thematic content of the vocational and specialized training includes knowledge and skills in the following scientific areas: sources;

- Economics of Environment and Natural Re-

- Resource Management;

- Environmental Policy.

These research areas include courses such as:

- Resource use and regional development;

- Management of natural resources;

- Monitoring and economic evaluation of the environment;

- Systems for environmental management;
- Methods of economic analysis of ecological projects;

- Economic instruments and environmental policy;

- Sustainable consumption and production;

- Organizational Behavior;

- Management consulting;

- Social security relations;

- Management of intellectual property.

Acquired scientific knowledge creates opportunities the master graduates to work as:

- Managers of environmental infrastructure at different levels of management in the public sector;

- Experts in public-private concession (evaluation) of natural resources;

- Managers and consultants in assessing and managing environmental projects;

- Consultants and supervisors of the System for management of environmental quality (ISO14001);

- Evaluators of agricultural land and biological assets in consulting firms;

- Specialists in public relations and in environmental issues in various business organizations;

- Experts in the Ministry of Environment and Water, Ministry of Agriculture and Food and others;

- Experts on environmental issues in NGOs, industry and other organizations and unions;

- Research workers and teachers in universities and research institutes.

Curriculum and programs of the master's degree in "Eco-economy" are developed in accordance with the Regulations of the UNWE system for accumulation and transfer of credits. For each course in the speciality plan a number of credits and requirements for their acquisition were approved.

In terms of content the curriculum of "Ecoeconomy" is directly and immediately connected with the mission, goals and objectives of education at the University.

The content of the courses included in the curriculum of the Master's degree is designed to prepare broad specialists who will perform managerial, technical and consulting services in various sectors of national economy. The preparation of students is consistent with the requirements of so- 
cial practice and the increased demands of citizens for green products and clean environment.

The courses in the Master's Plan are split in three groups:

- Compulsory

- Optional

- Facultative

Compulsory subjects are taught in the first semester and include courses such as Management of natural resources, Methods of economic analysis of environmental projects, Economic instruments of environmental policy, Monitoring and economic assessment of environment, Systems for management of environment. Their purpose is to provide in-depth knowledge of the problems of economics, politics and management of natural resources and environmental protection.

In the compulsory unit students receive systematic scientific knowledge of the methodological foundations of environmental policy and its economic instruments, of the development of European environmental policy and institutional and legal reform in the environmental area in the country.

The content of the course "Management of natural resources" includes expansion of the knowledge in natural resource management and its peculiarities in the use and protection of various renewable and non-renewable natural resources. Different types of use of natural resources and the specificity of their management are explained. Students are acquainted with the legal mechanisms of the management of natural resources and the economic approach and mechanisms of their usage.

The course "Monitoring and Economic assessment of environment" provides knowledge and skills for the creation and operation of European and national systems for environmental monitoring and of assessment methods for ecosystem services that are needed in different areas and levels in business, government and municipal level and NGOs. Students acquire knowledge of basic techniques and methods for assessing ecosystem services and assets. The training is entirely of practical character.

The course "Economic instruments of environmental policy" provides in-depth knowledge of the content and subordination of contemporary ecological problems and the types of ecological policy, on the mechanisms, economic instruments and principles of environmental policy. The fiscal mechanism such as environmental taxes and charges, the fund mechanism, the subsidies and particularly the environmentally-motivated subsidies, the scheme for environmental liability and compensation, the applied market-based instruments are explained in details.

The content of the course "Systems for management of environment" offers the students knowledge about the ecologically responsible policies on EU and on national level, information about the structure and requirements of the international standards of the series ISO 14 000: 2004 "Systems for management of the environment", about the European scheme for environmental management (EMAS). The students are acquainted with the methods for life cycle analysis and the importance of the "green" public procurement.

On the basis of general knowledge obtained from the compulsory subjects in the curriculum during the second semester five electives are offered from which students choose three. Eligible disciplines include Sustainable consumption and production, Use of natural resources and regional development, Organizational Behavior, Management Consulting and Social security relations.

The content of the curriculum of the discipline "Use of natural resources and regional development" provides an opportunity to deepen students' knowledge in the field of economics of natural resources and their use in a regional context. Deepening the understanding of the relationship man-society-environment and demonstration of the important role of human factor in environmental curriculum offers the course "Sustainable consumption and production."

Human factor problems and social problems are the subject of the course "Social security relations" and knowledge about adaptation to organizational change and overcoming resistance at the transition to other innovations and practices offer the course on "Organizational consulting." The contents of the program "Organizational Behavior" examines issues of individual differences and their impact on behavior, personal system and work motivation. Deepens the knowledge of behavioral patterns and problems of groups in organizations, of the development and functions of organizational culture and the problems of its management.

Tthe trends of production and consumptionq the methodological basis of discounting the intergenerational consumption, the production structure and its environmental impact are explained in the course "Sustainable consumption and production". In the course knowledge is provided about the im- 
pacts of world trade on the environment, about the production and technological capacity for environmentally friendly goods. Information is offered on the production and corporation footprint, on the principles of "zero" waste industrial networks and the trends of change of consumption behavior.

The preparation of students is expanded and enriched by studying the facultative discipline "Management of intellectual property."

The structure of the lessons of the curriculum of the speciality "Eco-economy" at the University is shown in Table 1 by groups of subjects.

Table 1

\section{Structure of the speciality curriculum of "Eco-economy" with types of courses for the Master's degree}

\begin{tabular}{lcc}
\hline \hline Type of courses & Number & Percent \\
\hline Compulsory & 5 & 45.5 \\
Optional & 5 & 45.5 \\
Facultative & 1 & 9 \\
Total & 11 & 100 \\
\hline \hline
\end{tabular}

Guidelines for optimizing the different scientific fields of the existing curriculum. Based on the experience of other countries and our experience in teaching on the speciality "Eco-economy" and on the review of curricula some restructuring of the curriculum and the type and number of courses in the mandatory and optional unit of the curriculum of the speciality "Eco-economy" from the UNWE master's degree is appropriate.

The number of compulsory courses must be the same, but the course "Methods of economic analysis of environmental projects" is appropriate to be moved to the optional unit and to be replaced by the optional discipline "Use of natural resources and regional development" due to the fact that in the bachelor's degree the students are educated of the basics of "Management of ecological projects", but they lack basic knowledge of regional development and use natural resources.

The number of eligible disciplines is desirable to be increased and we suggest "Ecotourism" and "Sustainable agriculture" as additional courses that focus on the ways of using natural resources for sustainable development of business units and regions.
The proposed changes of the existing curriculum in "Eco-economy" master's degree are depicted in Table 2.

Table 2

$$
\begin{aligned}
& \text { Content of the curriculum } \\
& \text { of the speciality "Eco-economy" }
\end{aligned}
$$

\begin{tabular}{ll}
\hline Courses included in the & $\begin{array}{l}\text { Suggested changes in courses } \\
\text { included in the UNWE curriculum }\end{array}$ \\
UNWE curriculum
\end{tabular}

\subsection{Compulsory courses}

1. Management of natural resources

1. Management of natural resources

2. Methods of economic analysis of environmental projects

3. Economic instruments of environmental policy

2. Use of natural resources and regional development

3. Economic instruments of environmental policy

4. Monitoring and

4. Monitoring and economic economic assessment of assessment of environment environment

5. Systems for management of

5. Systems for management of environment

environment

\subsection{Optional courses (three are chosen)}

$\begin{array}{ll}\begin{array}{l}\text { 1. Sustainable } \\ \text { consumption and } \\ \text { production }\end{array} & \begin{array}{c}\text { 1. Sustainable consumption and } \\ \text { production }\end{array} \\ \begin{array}{l}\text { 2. Use of natural resources } \\ \text { and regional } \\ \text { development }\end{array} & \begin{array}{l}\text { 2. Methods of economic analysis } \\ \text { of environmental projects }\end{array} \\ \begin{array}{l}\text { 3. Organizational } \\ \text { Behavior }\end{array} & \text { 3. Organizational Behavior } \\ \begin{array}{l}\text { 4. Management } \\ \text { Consulting }\end{array} & \text { 4. Management Consulting } \\ \begin{array}{l}\text { 5. Social security relations } \\ \text { 5. Social security relations }\end{array} \\ & \text { 6.Eco-tourism } \\ \text { 7. Sustainable development }\end{array}$

\subsection{Facultative courses}

\begin{tabular}{ll}
$\begin{array}{l}\text { 1. Management of } \\
\text { intellectual property }\end{array}$ & $\begin{array}{l}\text { 1. Management of intellectual } \\
\text { property }\end{array}$ \\
\hline
\end{tabular}

The content of the table shows the proposed project for the curriculum for master's degree of the speciality "Eco-economy" with courses that will help to improve it. 
The knowledge in natural resource management by extending the methodological and methodical approaches of regional development and expansion the extent of these disciplines with consideration of human and natural capital.

The optional special training by increasing the number of elective courses and by provision the opportunity to guide the preparation of students at the desirable direction.

The suggested changes in the courses and their distribution by semesters contribute to better understanding of the material.

In conclusion it can be stated that due to the short period of emergence and development of master's degree of the speciality "Eco-economy" in UNWE the proposed changes in the curriculum are the first attempt to reflect the specifics of the use and management of natural resources, and the methods for their study using variable management knowledge, practices and approaches and thus providing better opportunities for career development to the students.

\section{REFERENCES}

[1] Doichinova J., Kanchev I., Miteva A., Stoyanova Z. (2010): Managerial aspects of the eco-economy preparation of UNWE students, UI "Stopanstvo", Sophia.

[2] Kanchev I, Miteva A, Stoyanova Z. (2008): Education in specialty Eco-economy - opportunities and prospects. Management and Sustainable Development, vol. 3-4.

[3] Miteva A.: Students practical experience in real working environment - effective mechanism for development of students practical competences, UNWE conference "Development of practical competences of students through conducting students practical experience in real working environment".

[4] Stoyanova Z. (2009): Education of Integrated Ecological Assessment - main conclusions and suggestions, Management and Sustainable Development, vol. 3-4. 